\title{
Effects of exogenous applications of gibberellic acid on the development and quality of jabuticaba fruits
}

\section{Aplicación exógena del ácido giberélico en el desarrollo y la calidad de las frutas jabuticaba}
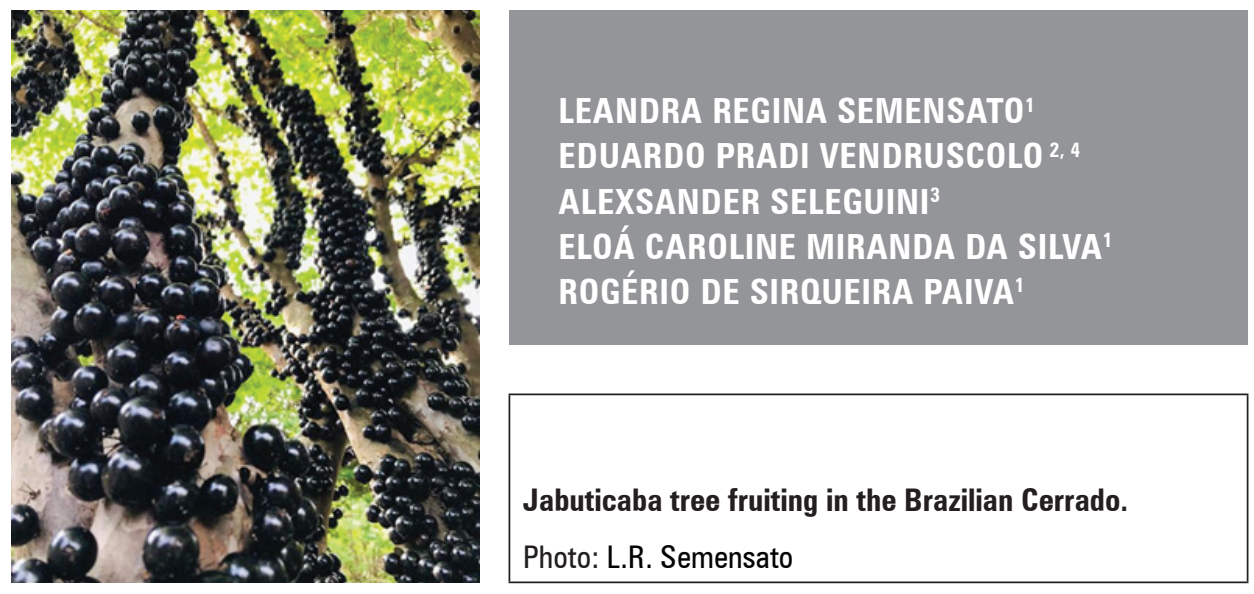

\section{ABSTRACT}

The jabuticaba is a native species that is seeing increased industrial exploitation because of its organoleptic and functional characteristics, making it attractive for food and pharmaceutical products. However, the fruit composition is not favorable for processing because of the abundance of seeds. Techniques already established for other crops should be studied to improve industrial use characteristics. Thus, the objective of this study was to evaluate the development and organoleptic quality of jaboticaba fruits as a function of exogenous applications of gibberellic acid on the stem of plants in three reproductive stages. The treatments consisted of four concentrations of gibberellic acid $\left(0,50,100\right.$ and $\left.200 \mathrm{mg} \mathrm{L}^{-1}\right)$ applied to jabuticaba plant stems in three reproductive phenological stages (flower buds, anthesis and post-flowering). A randomized complete block design was used with a factorial scheme $(4 \times 3)$ with six replications. It was observed that applications during anthesis and after flowering resulted in lower seed mass values and seed numbers and higher pulp yield, on average 23.08, 22.97 and $20.87 \%$, respectively. The treatment with flower buds and increased gibberellic acid concentrations also resulted in an increased pulp yield, up to a maximum of $12.58 \%$. Thus, it was concluded that the application of increasing concentrations of gibberellic acid, up to $200 \mathrm{mg} \mathrm{L}^{-1}$, improves pulp yield without altering the organoleptic characteristics of jabuticaba fruits and that applications at post-flowering or anthesis provide higher quality for industrial uses.

\footnotetext{
Additional key words: Plinia spp.; native species; growth regulator; plant physiology; subtropical fruiting; cell development.

UNIGOIÁS, Goiás University Center, Goiania (Brazil). ORCID Semensato, L.R.: 0000-0002-3961-6051; Silva, E.C.M.: 0000-0001-7254-1154; Paiva, R.S.: 0000-0002-6961-0611

2 Mato Grosso do Sul State University, Cassilandia (Brazil). ORCID Vendruscolo, E.P.: 0000-0002-3404-8534

3 Triângulo Mineiro Federal University, Iturama (Brazil). ORCID Seleguini, A.: 0000-0002-5762-9278

4 Corresponding author. agrovendruscolo@gmail.com
} 


\section{RESUMEN}

Jabuticaba representa una de las especies nativas de explotación industrial ascendente debido a sus características organolépticas y funcionales, lo que la hace atractiva para la producción de alimentos y productos farmacéuticos. Sin embargo, la composición de las frutas no es favorable para el procesamiento, ya que las semillas constituyen gran parte de su composición. El uso de técnicas ya establecidas para otros cultivos debe estudiarse para mejorar las características de uso industrial. Por lo tanto, el objetivo de este trabajo fue evaluar el desarrollo y la calidad organoléptica de la jabuticaba, en función de la aplicación exógena de ácido giberélico en el tallo de las plantas en tres etapas reproductivas. Para esto, los tratamientos consistieron en cuatro concentraciones de ácido giberélico $(0,50$, 100 y $200 \mathrm{mg} \mathrm{L}^{-1}$ ) aplicadas a los tallos de las plantas de jabuticaba en tres etapas fenológicas reproductivas (botones florales, antesis y post-floración). Se adoptó un diseño de bloques completos al azar en un esquema factorial $(4 \times 3)$ con seis repeticiones. Se observó que la aplicación durante la antesis y después de la floración dio como resultado valores más bajos de masa de semillas, número de semillas y mayor rendimiento de pulpa, en promedio 23.08, 22.97 y $20.87 \%$, respectivamente. Sobre el tratamiento de los botones florales el aumento de las concentraciones de ácido giberélico también dio como resultado un aumento del rendimiento de la pulpa hasta un máximo del 12,58\%. Por lo tanto, se concluyó que la aplicación de concentraciones crecientes de ácido giberélico, hasta $200 \mathrm{mg} \mathrm{L}^{-1}$, mejora el rendimiento de la pulpa, sin alterar las características organolépticas de los frutos de jabuticaba y que la aplicación en post-floración o antesis proporciona una mayor calidad para su industrialización.

Palabras clave adicionales: Plinia spp.; especies nativas; regulador de crecimiento; fisiología vegetal; fructificación subtropical; desarrollo celular.

Received for publication: 28-03-2020 Accepted for publication: 23-11-2020

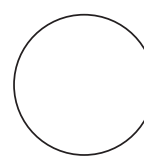

Greater concern for healthy habits has continuously increased demand for products with functional characteristics that have high levels of vitamins, minerals, and antioxidants. In this tendency, the introduction of native fruit species in industrial processes is observed, previously cultivated only on a small scale. Jabuticaba (Plinia spp.) fruits are rich in sugars, vitamins and other compounds that are beneficial to health and pleasant to the palate (Kosera Neto et al., 2018).

Despite the organoleptic characteristics of these fruits, which have been increasingly explored by agribusinesses, the large mass of seeds in relation to the total mass of the fruits decreases their processed uses. Technologies that increase pulp yield are sought. Gibberellic acid is used in the production of parthenocarpic fruits (Pandolfini, 2009), such as the atemoia (Pereira et al., 2014), pear (Sezerino and Orth, 2015) and pepper (Tofanelli et al., 2003).

The application of gibberellins during flowering replaces the active role of seeds that are aborted because of adverse climatic conditions or lack of pollination (Soares et al., 2001; Semensato et al., 2020).
However, despite the fact that gibberellin is the main active hormone regulating flowering, applications with high concentrations cause inhibition (Silva et al., 2017). In addition, the effectiveness of exogenous applications of gibberellin depends on the intrinsic factors of each species (Tofanelli et al., 2003; Pereira et al., 2014; Sezerino and Orth, 2015).

This study aimed to evaluate the development and organoleptic quality of jaboticaba fruits as a function of exogenous applications of gibberellic acid on the stem of plants in three reproductive stages.

\section{MATERIALS AND METHODS}

This experiment was installed in August of 2017 in a commercial orchard located in the municipality of Hidrolândia-GO, Brazil. The geographical coordinates are 16 $52^{\prime} 27^{\prime \prime} \mathrm{S}$ and $42^{\circ} 19^{\prime} 25^{\prime \prime} \mathrm{W}$. According to the Köppen classification, the climate is tropical Aw (warm and semi-humid, with a well-defined dry season from May to October) (Cardoso et al., 2014). The average altitude is $814 \mathrm{~m}$, with an average annual temperature of $22.8^{\circ} \mathrm{C}$ and an average rainfall of 1,411 


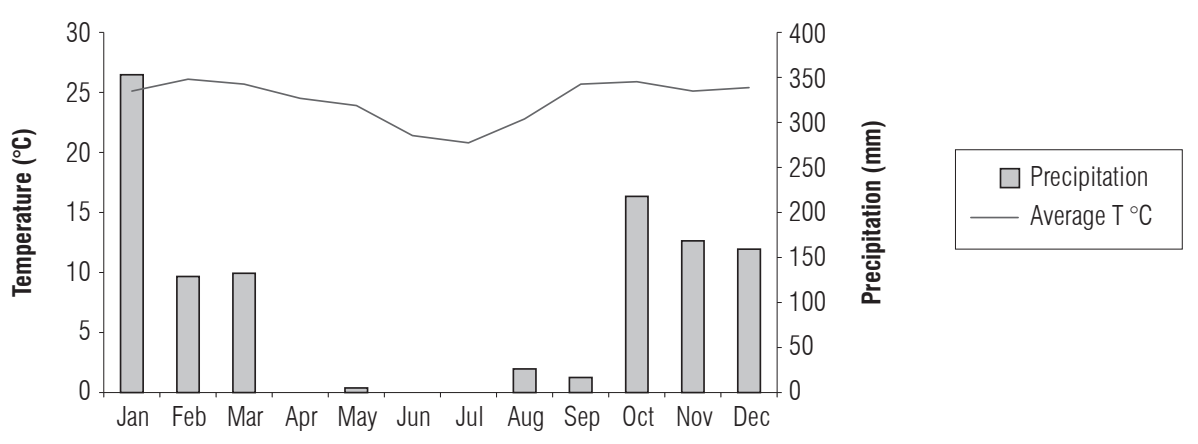

Figure 1. Temperature and precipitation averages in the municipality of Hidrolândia-GO during the study period in 2016.

mm year ${ }^{-1}$. For 2016, climatic data were obtained from a meteorological station in the municipality of Hidrolândia, about $8 \mathrm{~km}$ from the experiment area, for the temperature and precipitation variations (Fig. 1).

This experiment was conducted in an area containing 'Pingo-de-mel' jabuticaba trees (Plinia jabuticaba) (Vilela et al., 2012) with a free-standing cultivation in soil with a sandy-clay texture, at $3 \times 3 \mathrm{~m}$ spacing, irrigated by row and fertilized every two years with $1 \mathrm{~kg}$ of chicken manure per plant. For this experiment, six 18-year-old jabuticaba trees were randomly selected. The chemical analysis of the soil showed, at a depth of 0-0.2 m, levels of $\mathrm{Ca}^{2+}: 1.7 \mathrm{cmol}_{\mathrm{c}} \mathrm{dm}^{-3}, \mathrm{Mg}^{2+}: 0.4$ $\mathrm{cmol}_{\mathrm{c}} \mathrm{dm}^{-3}, \mathrm{~K}^{+}: 28.0 \mathrm{mg} \mathrm{dm}^{-3}$, P (Mehlich I): $1.87 \mathrm{mg}$ $\mathrm{dm}^{-3}, \mathrm{Al}^{3+}: 0.3 \mathrm{cmol}_{\mathrm{c}} \mathrm{dm}^{-3}, \mathrm{pH}\left(\mathrm{CaCl}_{2}\right): 4.51$, CTC: $5.17 \mathrm{cmol}_{\mathrm{c}} \mathrm{dm}^{-3}$, and $\mathrm{V}: 41.99 \%$. The granulometric analysis of the soil revealed $26 \mathrm{~g} \mathrm{~kg}^{-1}$ of clay, $18 \mathrm{~g} \mathrm{~kg}^{-1}$ of sand and $56 \mathrm{~g} \mathrm{~kg}^{-1}$ of silt at a depth of 0-0.2 m.

The treatments included the combination of four concentrations of gibberellic acid (0,50, 100 and 200 $\left.\mathrm{mg} \mathrm{L}^{-1}\right)$ applied on jabuticaba branches in three reproductive phenological stages (flower buds; anthesis and post-flowering). The experiment design used randomized blocks in a factorial scheme $(4 \times 3)$ with six replications. Each experiment unit consisted of two $50 \mathrm{~cm}$ branches per tree (block) that were evaluated during each phenological stage. A solution containing the growth regulator was applied with a manual sprayer $(20 \mathrm{~mL} /$ branch).

To define the phenological stages, the following parameters were adopted: flower buds - moment when swollen buds were observed; anthesis - observation of flower opening in more than $80 \%$ of flower buds; post-flowering - when small-green fruits appeared during the first stage of development in more than $80 \%$ of the floral structures.
After ripening, 15 fruits were randomly harvested from each plot for the quality assessment and then taken to the laboratory to be evaluated. The analyzed variables were: fresh fruit weight, fresh seed weight and fresh peel weight, obtained with an analytical scale; the number of seeds was counted; the longitudinal diameter and transversal diameter were measured with a digital caliper; the soluble solids were measured with an analogical refractometer; the titratable acidity was obtained with titration with a $\mathrm{NaOH}$ solution $(1 \mathrm{M})$, along with the ratio (ratio between soluble solids and titratable acidity).

The data were submitted to preliminary tests of normality and homoscedasticity and then to analysis of variance. The averages of the quantitative factor levels and concentrations of gibberellic acid were subjected to polynomial regression analysis. The means of the qualitative factor and phenophases were compared with each other with the Tukey test at $5 \%$. The statistical program was Sisvar 5.6 (Ferreira, 2014).

\section{RESULTS AND DISCUSSION}

There was no interaction between the factors, and the application of gibberellic acid did not influence the fruit fresh weight, regardless of the phenological stage in which the application occurred. However, for the other variables, there were significant differences between the means obtained with the treatments (Tab. 1).

The longitudinal and transverse diameters and fresh peel mass were higher in the fruits treated during the bud phenophase; however, they did not differ from the fruits that received the treatment during the post-flowering phenophase (Tab. 1). As compared 
Table 1. Fresh fruit weight (FFW), longitudinal diameter (LD), transversal diameter (TD), fresh seed weight (FSEW), fresh peel weight (FSW) and number of seeds (NS) in fruits from jabuticaba trees treated with gibberellic acid in different phenological stages.

\begin{tabular}{|l|c|c|c|c|c|c|}
\hline \multicolumn{1}{|c|}{ Phenophase } & FFW $(\mathrm{g})$ & LD $(\mathrm{mm})$ & TD $(\mathrm{mm})$ & FSEW $(\mathrm{g})$ & FSW $(\mathrm{g})$ & NS $(-)$ \\
\hline Flower-buds & $3.43 \mathrm{a}$ & $16.65 \mathrm{a}$ & $16.66 \mathrm{a}$ & $1.19 \mathrm{a}$ & $0.26 \mathrm{a}$ & $1.72 \mathrm{a}$ \\
\hline Anthesis & $3.13 \mathrm{a}$ & $14.45 \mathrm{~b}$ & $14.46 \mathrm{~b}$ & $1.05 \mathrm{~b}$ & $0.18 \mathrm{~b}$ & $1.28 \mathrm{~b}$ \\
\hline Post-flowering & $3.46 \mathrm{a}$ & $16.32 \mathrm{ab}$ & $16.30 \mathrm{ab}$ & $1.13 \mathrm{ab}$ & $0.22 \mathrm{~b}$ & $1.37 \mathrm{~b}$ \\
\hline LSD & 0.37 & 1.93 & 1.92 & 0.13 & 0.04 & 0.15 \\
\hline CV\% & 16.35 & 17.53 & 17.43 & 17.09 & 25.89 & 14.33 \\
\hline
\end{tabular}

Means followed by the same letter in a column do not differ according to Tukey's test at 5\% probability. LSD = Least significant difference; CV = Coefficient of variation.

to the fruits treated in anthesis, applications of gibberellic acid during the bud phenophase increased the characteristics longitudinal diameter, transversal diameter, and fresh peel mass by 15.23, 15.21 and $13.33 \%$, respectively.

The application of gibberellic acid during the anthesis and post-flowering phenophases significantly decreased the fresh mass and number of seeds (Tab. 1). Under these conditions, the applications during anthesis decreased the fresh weight and the number of seeds by 30.77 and $25.58 \%$, respectively, as compared to the applications on flower buds. As compared to the applications on flower buds, the post-flowering applications reduced these characteristics by 15.39 and $20.35 \%$, respectively.

There was a linear decrease in the variables fruit fresh weight, peel fresh weight and seed fresh weight as the concentrations of gibberellic acid increased, up to the maximum concentration of $200 \mathrm{mg} \mathrm{L}^{-1}$ (Fig. $2)$. At this concentration, the reduction was 16.14 ,
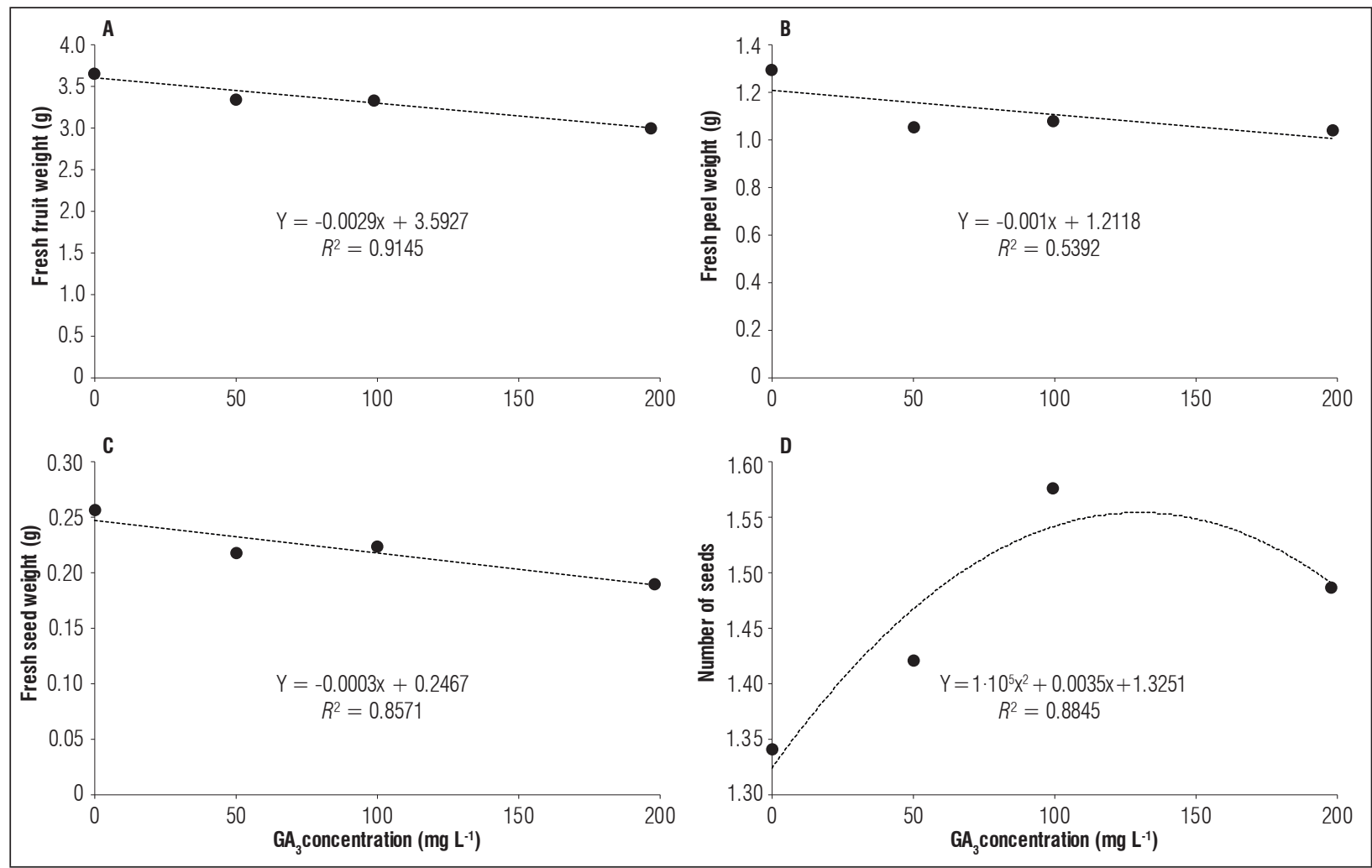

Figure 2. Fruit fresh weight (A), peel fresh weight (B), seed fresh weight (C) and number of seeds (D) of jabuticaba fruits treated with increasing concentrations of gibberellic acid. 
16.50 and $24.32 \%$, respectively, for the characteristics of fresh fruit mass, fresh peel mass and fresh seed mass. The reduction in the fresh weight of the peels and seeds was responsible for $50 \%$ of the reduction in fruit fresh weight.

A decrease in fruit fresh mass may be related to greater fruit fixation provided by the action of gibberellic acid on the production of proteolytic enzymes (Vieira et al., 2008a). These enzymes are responsible for the release of tryptophan, which in turn acts as an indolacetic acid precursor, which prevents the formation of the abscission layer that connects fruits to plants (Pires and Botelho, 2001).

In addition, the decrease in the mass of the fruits, peels and seeds and the increase in the number of seeds with the increases concentrations of gibberellic acid may have resulted from the inverse relationship between cell size and number of cells because applications of this phytohormone increase cell division activity while decreasing cell volume, resulting in a compensatory effect for some species, such as grapes (Vieira et al., 2008b).

There were no effects from the application of gibberellic acid in the different phenophases for the organoleptic characteristics titratable acidity, soluble solids and ratio (Tab. 2). However, the application of phytohormone during anthesis and post-flowering increased pulp yield by 21.43 and $20.31 \%$, respectively, as compared to the flower bud phenophase.

For the pulp yield, a linear and increasing response was obtained for the concentrations of gibberellic acid (Fig. 3). The increase in the phytohormone concentrations, up to a concentration of $200 \mathrm{mg} \mathrm{L}^{-1}$, resulted in an increase in this characteristic of $12.58 \%$, as compared to the control treatment, which did not have an application of gibberellic acid.

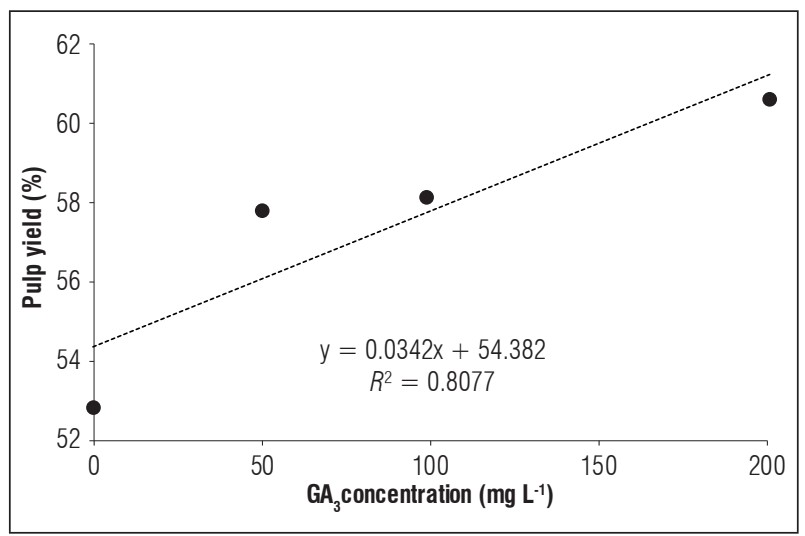

Figure 3. Pulp yield of jabuticaba fruits treated with increasing concentrations of gibberellic acid.

Exogenous applications of gibberellic acid suppress seminal phytohormone production activity (Tecchio et al., 2009), which is responsible for the formation and distribution of fruit composition through cell division and elongation (Taiz et al., 2017). Increasing concentrations of gibberellic acid result in seed atrophy, which have their functionality reduced by the presence of the synthetic hormone, which starts to play the role of the natural hormone (Pereira et al., 2014). Despite inhibiting the development of seeds, this hormone supplies their activities, maintaining the plant's capacity to accumulate sugars and properly develop fruit size (Taiz et al., 2017).

\section{CONCLUSION}

Exogenous applications of gibberellic acid, up to a concentration of $200 \mathrm{mg} \mathrm{L}^{-1}$, during anthesis or postflowering improve the industrial characteristics of jabuticaba fruits, increasing pulp yield without affecting quality.

Table 2. Titratable acidity (TA), soluble solids (SS), ratio and pulp yield (PY) in fruits from jabuticaba trees treated with gibberellic acid in different phenological stages. Hidrolândia-GO, 2016.

\begin{tabular}{|l|c|c|c|c|}
\hline Phenophase & $\begin{array}{c}\text { TA } \\
\text { (mg citric acid/100 g) }\end{array}$ & $\begin{array}{c}\text { SS } \\
\left({ }^{\circ} \text { Brix) }\right.\end{array}$ & $\begin{array}{c}\text { Ratio } \\
(-)\end{array}$ & $\begin{array}{c}\text { PY } \\
(\%)\end{array}$ \\
\hline Flower-buds & $1.23 \mathrm{a}$ & $12.04 \mathrm{a}$ & $11.43 \mathrm{a}$ & $50.08 \mathrm{~b}$ \\
\hline Anthesis & $1.03 \mathrm{a}$ & $13.17 \mathrm{a}$ & $15.71 \mathrm{a}$ & $60.81 \mathrm{a}$ \\
\hline Post-flowering & $1.06 \mathrm{a}$ & $12.68 \mathrm{a}$ & $14.83 \mathrm{a}$ & $60.25 \mathrm{a}$ \\
\hline LSD & 0.24 & 1.16 & 4.67 & 5.03 \\
\hline CV\% & 30.69 & 13.24 & 48.02 & 12.6 \\
\hline
\end{tabular}

Means followed by the same letter in a columns do not differ according to Tukey's test at $5 \%$ probability. LSD $=$ Least significant difference; CV $=$ Coefficient of variation. 
This is a promising technique for increasing the use of this species in industrial processes, opening the possibility for applications on other native species.

Conflict of interests: The manuscript was prepared and reviewed with the participation of the authors, who declare that there exists no conflict of interest that puts at risk the validity of the presented results.

\section{BIBLIOGRAPHIC REFERENCES}

Cardoso, M.R.D., F.F.N. Marcuzzo, and J.R. Barros. 2014. Classificação climática de Köppen-Geiger para o estado de Goiás e o Distrito Federal. Acta Geogr. 8(16), 40-55.

Ferreira, D.F. 2014. Sisvar: A guide for its Bootstrap procedures in multiple comparisons. Ciênc. Agrotec. 38(2), 109-112. Doi: 10.1590/S1413-70542014000200001

Kosera Neto, C., A.H. Porto, M.D. Silva, J.C. Radaelli, and A. Wagner Júnior. 2018. Reproductive and vegetative behavior of hybrid jabuticaba tree under flowering induction. Pesqui. Agropecu. Trop. 48(2), 118-125. Doi: 10.1590/1983-40632018v4851911

Pandolfini, T. 2009. Seedless fruit production by hormonal regulation of fruit set. Nutrients 1(2), 168-177. Doi: 10.3390/nu1020168

Pereira, M.C.T., J.H. Crane, S. Nietsche, W. Montas, and M.A. Santos. 2014. Reguladores de crescimento na frutificação efetiva e qualidade de frutos partenocárpicos de atemoia 'Gefner'. Pesq. Agropec. Bras. 49(4), 281-289. Doi: 10.1590/S0100-204X2014000400006

Pires, E.J.P. and R.V. Botelho. 2001. Uso de reguladores vegetais na cultura da videira. p. 129. In: Libro de resúmenes, Simpósio Brasileiro sobre Uvas de Mesa. Fundação de Amparo à Pesquisa do Estado de São Paulo, Ilha Solteira, Brazil.

Semensato, L.R., E.P.V. Vendruscolo, A. Seleguini, P.A. Batista Filho, E.C.M. Silva, and T.P. Silva. 2020. Fenologia, produtividade e qualidade de frutos de jabuticabeiras de diferentes idades das plantas. Iheringia Sér. Bot. 75, e2020013. Doi: 10.21826/2446-82312020v75e2020013

Sezerino, A.A. and A.I. Orth. 2015. Pollination of the portuguese pear in Bom Retiro-SC, Brazil. Rev. Bras. Frutic. 37(4), 943-951. Doi: 10.1590/0100-2945-209/14

Silva, K.K.A., E.O. Ono, M.A.C. Mouco, G.J. Nogueira, R.J.M. Souza, N.C. Silva, and R.D.C.B. Silva. 2017. Uniconazole no florescimento e produção da mangueira (Mangifera indica L.) cv. Palmer. Magistra 26(4), 505-514.

Soares, J., A. Silva, and J. Alexandre. 2001. O livro da pera rocha. Associação Nacional de Produtores de Pera Rocha, Cadaval, Brazil.

Taiz, L., E. Zeiger, I.M. Møller, and A. Murphy. 2017. Plant physiology. $6^{\text {th }}$ ed. Sinauer Associates Publishers, Sunderland, MA.

Tecchio, M.A., M.F. Moura, J.L. Hernandes, E.J. Paioli-Pires, M.M. Terra, and S. Leonel. 2009. Efeito do ácido giberélico nas características ampelométricas dos cachos de uva 'A Dona'e 'Marte'. Sci. Agrar. 10(4), 297-304. Doi: 10.5380/rsa.v10i4.14800

Tofanelli, M.B.D., J.E. Amaya-Robles, J.D. Rodrigues, and E.O. Ono. 2003. Ácido giberélico na produção de frutos partenocárpicos de pimenta. Hortic. Bras. 21(1), 116-118. Doi: 10.1590/S0102-05362003000100024

Vieira, C.R.Y.I., E.J.P. Pires, M.M. Terra, M.A. Tecchio, and R.V. Botelho. 2008a. Efeitos do ácido giberélico e do thidiazuron sobre as características dos frutos e do mosto da uva 'Niagara Rosada'. Rev. Bras. Frutic. 30(1), 12-19. Doi: 10.1590/S0100-29452008000100005

Vieira, C.R.Y.I., E.J.P. Pires, M.M. Terra, M.A. Tecchio, and M.D.C. Vieira. 2008b. Reguladores vegetais influenciando número e tamanho de células das bagas da uva 'Niagara Rosada'. Rev. Bras. Frutic. 30(1), 25-30. Doi: 10.1590/S0100-29452008000100007

Vilela, R.C.F., J. Assis, L. Nóbrega Filho, and B.F. Viana. 2012. Sistema reprodutivo e diversidade genética de quatro espécies de Myrciaria (Myrtaceae, Jabuticabeiras). Acta Bot. Bras. 26(4), 727-734. Doi: 10.1590/ S0102-33062012000400002 